\title{
建築用材料としてのステンレス 鋼*
}

\section{1.はじめに}

Stainless steel の“stain”は“よごれ”, “さび”,であ り, “less than another metal で, non-stain ではな い。建築外装材としてのステンレス材を考光た場合，化 学工業等に使用する場合のように苛酷な腐食条件々は異 なるが，やはり外界の条件，たと放ば街路の土砂，建設 中の鉄骨等の鉄粉，交通機関のレール鉄粉，銅粉，煤煙 中のカーボン, 有害ガス, 自動車排気ガス中の硫化 水 素，亜硫酸ガス，潮風や台風の塩分等々，金属面熖食 を起こさせる因子は数兄きれない。これらの因子も乾燥 状態であ机ば，腐食の進行は少なく，払拭することによ って清浄な面を維持できるはずである。しかしわが国の ように湿度の高いところでは特に問題があると思う。湿 度に招いて日本の平均は 75.6\%(1930 ～1960), 米国の平均 $64 \%(1950 \sim 1960)$, 雨量に扮いて，1,470 mm (日本), 同じ く $990 \mathrm{~mm}$ (米国)と差があり，湿気の多 いことはそれだけ wet corrosion に関 係してくる訳である。

\section{2. 建築用ステンレスの種類とよごれ}

\section{$2 \cdot 1$ 種 類}

建筑に使用されているステンレス材を 表 1 亿示す。一般にSUS 27 が多く外装 打よび内装に使用され，SUS 27 につい で SUS 24 が屋内の比較的湿気を伴わな いところに使用される。海岸地帯, 工場 地帯の腐食環境にはたまに SUS 32 のモ リブデンのはいったステンレスが外装屋 根材に使用されることがある。

$2 \cdot 2$ ステンレス外装のよごれ

外装に括けるステンレスのよごれを大別

表 1 建築用ステンレス鋼材

\begin{tabular}{l|l}
\hline \hline J I S & 成 \\
\hline SUS 51 & 分 \\
SUS 52 & $13 \mathrm{Cr}$ (棒材) \\
SUS 24 & $18 \mathrm{Cr}$ \\
SUS 27 & $18 \mathrm{Cr}-8 \mathrm{Ni}$ \\
SUS 32 & $18-8 \mathrm{Mo}$ \\
\hline
\end{tabular}

* 日本金属腐食会議主催シンポジウム（昭和 42 年 4 月 27 日, 東京) 飞乱いて講演

** 日本治金工業株式会社（東京都中央区宝町 1 の 7 味の素ビル)
すると次の 3 区分となる。

（1）ステンレスの表面に単にほこり，鉄粉，土砂等 が付着した程度の軽微なよごれ状態

（2）付着物が長期（6力月以上）に放置されて取り 除き困難となり，末た一部変色したひどいよごれ状態， この場合付着物の裏面が酸素不供給等孔助長して, 斑状 に軽微な腐食を受けることもある。

（3）亜硫酸ガスその他有害ガス，台風時の濃厚な塩 分を含む潮風等によって，全面変色，あるいは軽い点食 を生じた状態。

3. 大気暴露試駼結果

$3 \cdot 1$ 日本における暴露試験（日本治金工業）

（1）暴露方法 南向 $30^{\circ}$ 傾斜

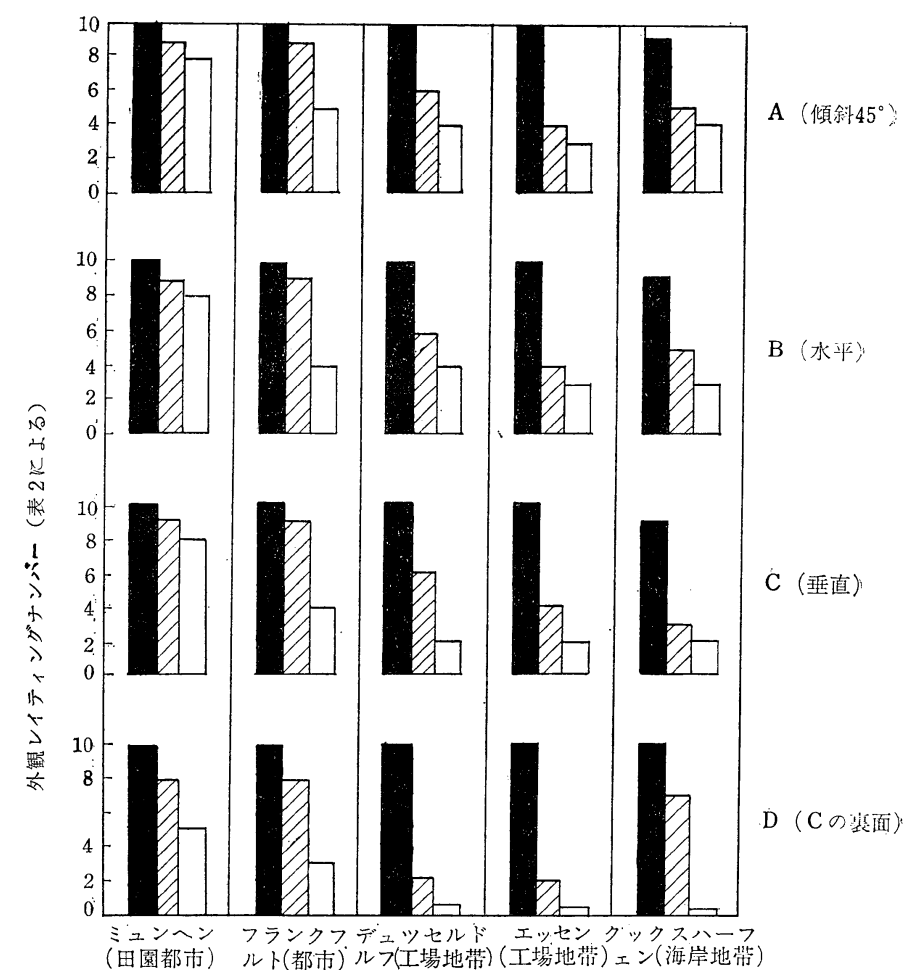

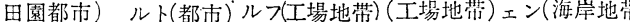

$18 \mathrm{Cr}-10 \mathrm{Ni}-2 \mathrm{Mo}$ JIS SUS 32

$\square 18 \mathrm{Cr}-8 \mathrm{Ni}$

SUS 27

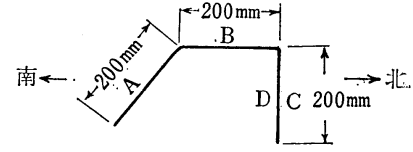

$18 \mathrm{Cr}$

SUS 24

図 1 ドイッに抢ける大気暴露試験結果 
表 2 暴露試験結果評価レイティングナンバー (日本，ドイッ)

\begin{tabular}{|c|c|c|c|}
\hline $\begin{array}{l}\text { レイティン } \\
\text { グナンバー }\end{array}$ & 噟食面積率 (\%) & $\begin{array}{l}\text { レィティン } \\
\text { グナンバー }\end{array}$ & 腐食面積率 (\%) \\
\hline 10 & 0 & 4 & 2.5 以上 5.0 未満 \\
\hline 9 & 0.10 未嗬 & 3 & 5.0 以上 10.0 未満 \\
\hline 8 & 0.10 以上 0.25 未満 & 2 & 10.0 以上 25.0 未満 \\
\hline 7 & 0.25 以上 0.50 未满 & 1 & 25.0 以上 50 末淽 \\
\hline 6 & 0.50 以上 1.0 未満 & 0 & 50以上 \\
\hline 5 & 1.0 以上 2.5 未満 & & \\
\hline
\end{tabular}

表 3 日本に打ける大気暴露試験結果(日本治金工業)

\begin{tabular}{|c|c|c|c|c|c|c|c|}
\hline \multirow{2}{*}{ 材 質 } & \multirow{2}{*}{ 表面仕上 } & \multicolumn{6}{|c|}{ 外観レイティングナンバー（表 2 にる) } \\
\hline & & 黑露前 & 住宅地 & 田園都市 & 市街工場 & $\begin{array}{l}\text { 臨海工 } \\
\text { 業地带 }\end{array}$ & 海岸地帶 \\
\hline \multirow{2}{*}{ SU S 24} & $2 B$ & 10 & $y$ & 9 & 7 & 4 & 4 \\
\hline & No. 4 & 10 & 8.5 & 9 & 4 & 3 & 2 \\
\hline \multirow{4}{*}{ SUS 27 } & $2 \mathrm{D}$ & 10 & 9.5 & 9 & 8.5 & 6 & 6 \\
\hline & $2 B$ & 10 & 9.5 & 9 & 8.5 & 6 & 6 \\
\hline & No. 4 & 10 & 9 & 9 & 8 & 6 & 5.5 \\
\hline & ヘアライン & 10 & 9.5 & 9 & 8 & 5.5 & 5 \\
\hline \multirow{2}{*}{ SUS 32} & $2 \mathrm{~B}$ & 10 & 9.5 & 9 & 8.5 & 7 & 7.5 \\
\hline & No. 4 & 10 & 9.5 & 9.5 & 8 & 6 & 6.5 \\
\hline
\end{tabular}

（2）試験場所 都市住宅地, 田園都市, 都市工業地 帯, 臨海工業地带, 海岸地帯

（3）評価方法 表面外観の腐食（変色）面積を\%で 表 2 に示す。

（4）試験結果 試験結果を総括して表 3 に示す。

\section{$3 \cdot 2$ ドイツにおける暴露試験}

（1）評価方法 $3 \cdot 1$ (3) 表 2 と同じ。

(2) 試験結果 図 1 亿その結果を示す。

\section{$3 \cdot 3$ イギリスにおける暴露試験}

（1）評価方法 レイティングナンバーは表 4 に示 क。

（2）試験結果 イギリスに拈けるアメリカ製，イギ リス製ステンレス材の暴露試験結果を表 5 に示す。
表 4 暴露試験結果評価レイティングナンバー

(イギリス)

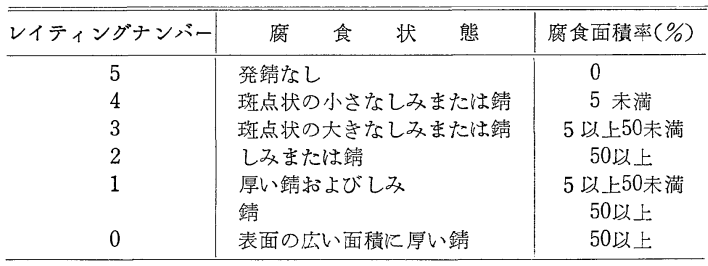

試験結果を表 5 亿示す

以上暴露試験の結果を総合判断してみると, SUS 24 材は外装に使用することは不適当であり，工業地帯，臨 海地带に SUS 32 材を使用することが裏づけられると思 5。わが国ではまだ SUS 32 の外装使用は一，二を除い て行なわれていないが今後考慮されるべきことと思う。

\section{4. ステンレス外装のメンテナンス}

ステンレス外装をはじめ建材の手入れ法は，その環境 によって抒拉い支配されるが，“よごれ”, “さび”の犯 人は外敵であり，早めに定期清掃を開始し，落ちにくい 付着物とならぬらちに表面の払拭を手まめ行ならこと が大切であり, “ステンレスはさびないから清掃は不要 だ”という間違った通念は打破されるべきである。設計 の段階から水はけの容易, 隅肉の除去, ゴンドラの設 置, 空際の用水確保, 足場等広範囲に清掃しやすいよう に考慮が払われなければならない。ビル管理者も十分清 掃の必要性を理解して, 定期清掃のプログラムを立てる べきである。

\section{$4 \cdot 1$ 清掃方法}

（1）軽度のよごれは，空拭き，水拭き程度で取り除 くことができるが，ひどいよごれとなると洗剤または薬 液を用いねばならない。使用する洗剤, 薬液の $\mathrm{pH}$ は $6 \sim 9$ 程度の弱酸性または弱アルカリ性のものがよい。

表 5 イギリスに和ける大気暴露試験結果（表 4 による）

\begin{tabular}{|c|c|c|c|c|c|c|c|c|c|c|c|c|}
\hline 供 & 試 & \multirow{2}{*}{$\begin{array}{c}\text { 仕 } \\
\text { 上 } \\
\text { No. }\end{array}$} & \multicolumn{2}{|c|}{ 工 $(\text { 場クド地 })^{\text {荋 }}$} & \multicolumn{2}{|c|}{$\begin{array}{l}\text { 工 場 地 带 } \\
\text { (パーシグガム) }\end{array}$} & \multicolumn{2}{|c|}{$\begin{array}{l}\text { (住 宅 地 带 } \\
\text { (クンン) }\end{array}$} & \multicolumn{2}{|c|}{ 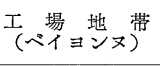 } & \multicolumn{2}{|c|}{$\left(\begin{array}{l}\text { 海 岸 地 带 } \\
\text { (キニーレビーチ) }\end{array}\right.$} \\
\hline 材＼cjkstart質 & $\begin{array}{l}\text { 製造国名 } \\
\text { アメリカ } \\
\text { イギリスの別 }\end{array}$ & & 表 & 裏 & 表 & 裹 & 表 & 裹 & 表 & 裏 & 表 & 裹 \\
\hline \multirow{2}{*}{$\begin{array}{l}\mathrm{SUS} 24 \\
18 \mathrm{Cr}\end{array}$} & アメリカ製 & $\begin{array}{c}2 \mathrm{~B} \\
4\end{array}$ & $\begin{array}{l}0 \\
0\end{array}$ & $\begin{array}{l}0 \\
0\end{array}$ & $\begin{array}{l}0 \\
0\end{array}$ & $\begin{array}{l}0 \\
0\end{array}$ & $\begin{array}{l}2 \\
2\end{array}$ & $\begin{array}{l}1 \\
1\end{array}$ & $\begin{array}{l}5 \\
5\end{array}$ & $\begin{array}{l}4 \\
4\end{array}$ & $\begin{array}{l}2 \\
2\end{array}$ & - \\
\hline & イギリス製 & $\begin{array}{c}\mathrm{E} \mathrm{P*} \\
2 \mathrm{~B} \\
3\end{array}$ & $\begin{array}{l}0 \\
0 \\
0\end{array}$ & $\begin{array}{l}0 \\
0 \\
0\end{array}$ & $\begin{array}{l}0 \\
0 \\
0\end{array}$ & $\begin{array}{l}0 \\
0 \\
0\end{array}$ & $\begin{array}{l}3 \\
3 \\
2\end{array}$ & $\begin{array}{l}2 \\
2 \\
1\end{array}$ & $\begin{array}{l}5 \\
5 \\
5\end{array}$ & $\begin{array}{l}4 \\
4 \\
4\end{array}$ & $\begin{array}{l}3 \\
3 \\
2 \\
\end{array}$ & $\begin{array}{l}- \\
-\end{array}$ \\
\hline \multirow[b]{2}{*}{$\begin{array}{c}\text { SUS } 27 \\
18 \mathrm{Cr}-8 \mathrm{Ni}\end{array}$} & アメリカ製 & $\begin{array}{c}2 \mathrm{~B} \\
4\end{array}$ & $\begin{array}{l}3 \\
2\end{array}$ & $\begin{array}{l}4 \\
3\end{array}$ & $\begin{array}{l}3 \\
3\end{array}$ & $\begin{array}{l}1 \\
1\end{array}$ & $\begin{array}{l}4 \\
4\end{array}$ & $\begin{array}{l}4 \\
4\end{array}$ & $\begin{array}{l}5 \\
5\end{array}$ & $\begin{array}{l}4 \\
4\end{array}$ & $\begin{array}{l}3 \\
3\end{array}$ & - \\
\hline & イギリス製 & $\begin{array}{c}\mathrm{E} \mathrm{P}^{*} \\
2 \mathrm{~B} \\
3\end{array}$ & $\begin{array}{l}5 \\
2 \\
3\end{array}$ & $\begin{array}{l}5 \\
3 \\
4\end{array}$ & $\begin{array}{l}4 \\
2 \\
2\end{array}$ & $\begin{array}{l}4 \\
1 \\
1\end{array}$ & $\begin{array}{l}5 \\
4 \\
4\end{array}$ & $\begin{array}{l}5 \\
5 \\
4 \\
\end{array}$ & $\begin{array}{l}5 \\
5 \\
5 \\
\end{array}$ & $\begin{array}{l}4 \\
4 \\
4\end{array}$ & $\begin{array}{l}4 \\
3 \\
3 \\
\end{array}$ & $\begin{array}{l}- \\
- \\
-\end{array}$ \\
\hline \multirow{2}{*}{$\begin{array}{l}\text { SUS } 32 \\
18 \mathrm{Cr}- \\
10 \mathrm{Ni}- \\
2.5 \mathrm{Mo}\end{array}$} & アメリカ製 & $\begin{array}{c}2 \mathrm{~B} \\
4\end{array}$ & $\begin{array}{l}5 \\
5\end{array}$ & $\begin{array}{l}5 \\
4\end{array}$ & $\begin{array}{l}5 \\
5\end{array}$ & $\begin{array}{l}5 \\
5\end{array}$ & $\begin{array}{l}5 \\
5\end{array}$ & $\begin{array}{l}5 \\
5\end{array}$ & $\begin{array}{l}5 \\
5\end{array}$ & $\begin{array}{l}5 \\
5\end{array}$ & $\begin{array}{l}4 \\
4\end{array}$ & - \\
\hline & イギリス製 & $\begin{array}{c}\mathrm{EP}^{*} \\
2 \mathrm{~B} \\
3\end{array}$ & $\begin{array}{l}5 \\
5 \\
5\end{array}$ & $\begin{array}{l}4 \\
4 \\
4\end{array}$ & $\begin{array}{l}5 \\
5 \\
5\end{array}$ & $\begin{array}{l}5 \\
5 \\
5\end{array}$ & $\begin{array}{l}5 \\
5 \\
5\end{array}$ & $\begin{array}{l}5 \\
5 \\
5\end{array}$ & $\begin{array}{l}5 \\
5 \\
5\end{array}$ & $\begin{array}{l}5 \\
5 \\
5\end{array}$ & $\begin{array}{l}4 \\
4 \\
4\end{array}$ & $\begin{array}{l}- \\
- \\
-\end{array}$ \\
\hline
\end{tabular}

（注） $\mathrm{EP}:$ 電解研摩 
これらを布またはスポンジに含ませて研摩面に沿って拭 き取る。それでるよごれが十分に拭き取れない場合に は,さらにみがき粉 (200メッシュ以下の炭酸カルシウ ム, チョーク粉), 水ペーパーなどを加兄て行ならとよ い。布やスポンジの代りにナイロンパッド, へちま, 普 通たわし，ステンレスたわしなど使用してもよい。

洗剂, 薬液を使用した後は水洗いを十分にし，できる だけ空拭きをする。スチールウール，サンドペーパーは 使ってはならない。一時的にはよごれを除去できたよう にみ觉るが，こまかい鉄粉や砂土が表面伐留して，後 のさびやよごれの原因となることがあるからである。

（2）日常人の手にふれるドアー引手，押板，エレベ ーター, プッシュプレート，スイッチ板なぞについた指 紋はなかなか取りにくいが，薄い油性またはワックスを 含むクリーナーでぬぐいとることができる。ふき取った 後は再び上記クリーナーの薄いフィルムが残る程度に塗 布して捄くと事後の指紋もつきにくい。

（3）ステンレスの表面にクリヤラッカーを使用する 場合がある。これはステンレスの加工または工事中，そ の表面にきずのつくのを防ぎ，または指絞あとのつくの を防ぐためである。しかしいずれにせよ長期放置して拉 くとラッカーは次第に老化する。屋内に打いては 1 ～ 1 年半, 屋外飞赫いては 6 10 月くらい経た場合, 小割 れを生じたり，室内に和いてはタバコの煙のために黄変 色したりすることがある。ラッカーの除去については原 則として建物完成直後あるいは $1 \sim 2$ カ月後には除去し て裸のステンレス表面を定期的に清掃し，美麗な肌を維 持すべきである。

（4） ステンレス清掃薬品名（例）

清掃薬品にはいろいろめって万能薬はない。参考表 6 に数例をめげたが，実際に使用して試してみることが
表 6 ステンレス清掃薬品名（例）

\begin{tabular}{|c|c|}
\hline 状態 & 品 \\
\hline よごれ & 中性洗剂各種, 石鹼水, アンモニア水 \\
\hline 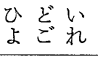 & $\begin{array}{l}\text { ステンクリーナー, 水ガラス, ステン } 300 \text { 番, カープレ } \\
\text { ート, グラスター, ニーダル }\end{array}$ \\
\hline 油 脂 類 & $\begin{array}{l}\text { ガソリン, ケロシン, ナフサのような良質溶㓣, ベンジ } \\
\text { ン, テレピン泊 }\end{array}$ \\
\hline ラッカー & $\begin{array}{l}\text { ステン } 300, \text { 岸酸カルシウム, 軽石粉, チョーク粉, 合 } \\
\text { 成塗料溶剤, イージープライト, シリコーン, トリクレ } \\
\text { ーン, テトロフィドロフラン }\end{array}$ \\
\hline 紋 & ワックス類, イージーブライト, シリュン \\
\hline
\end{tabular}

（注）溶剤類は火気《注意

実際的である。

\section{5. 結 び}

建築用内外装に使用されるステンレスは, その環境に より選定さるべきであり, 実際問題として外装にはSUS 27 を主体に, 海岸, 工業地帯には場合によって SUS 32 が使用され, 内装に和いて湿気を伴わないところに SUS 24 が使用される。

メンテナンスについては, ステンレスはさびないもの だとの先入観のため，メンテナンスをな括ざりにし，よ ごれがひどくなってから，峛わてて清掃に取りかかるこ とが多い。ステンレスの耐食性は他の金属に比較しては るかにすぐれているが，絶体にさびないわけではない。

最も大切なことは，よごれやさびの原因となるるのを 速やかに取り除くことである。常時または定期的に手入 れを行なっているかぎり，ステンレスはいつまでもさび ることを知らない金属である。常時または定期清掃する ことは非常に手間のかかるような感じを与えるが，よご れがひどくなってからの清掃に比べたら，経費の点で も, 清掃効果の点でも結局得策である。その建物周囲の 環境によってそのよごれの度合は非常に異なるものであ り，その度合によって清掃計画が立てられる。 